\title{
Calculation of Temperature Coefficients of Reactivity for EBR-II Kinetic Anaiyses*
}

To be presented

$$
\text { at the }
$$

American Nuclear Society Meeting

June 7-11, 1987

Dallas, Texas

*Work supported by the U. S. Department of Energy, Reactor Systems, Development and Technology, under Contract W-31-109-Eng-38. 


\title{
Calculation of Temperature Coefficients of Reactivity for EBR-II Kinetic Analyses*
}

\author{
by \\ D. Meneghetti and D. A. Kucera
}

Temperature coefficients of reactivity for use in coupled neutronicsthermohydraulics kinetics codes, as for example the EROS ${ }^{l}$ code used for Experimental Breeder Reactor-II (EBR-II) kinetic analyses, are both loading and problem-modeling sensitive. To enable appropriate temperature coefficients to be calculated for differing loading configurations and differing subassembly groupings in the kinetics analyses, an addition (TEMCO) has been made to the EBRPOCO ${ }^{2}$ code. EBRPUCO calculates detailed axially-delineated contributions of the linear and Doppler components of the power-reactivitydecrement (PRD) for every subassembly and control rod location in an EBR-II configuration.

Because EBRPOCO calculations of the PRD components require correspondingly detailed axially-delineated temperatures of the intra-subassembly components, the ratio of a positional reactivity (or appropriate intersubassembly sum) relative to the corresponding positional temperature increment (or that in the subassembiy chosen to represent that sum in a kinetics modeling) above coolant inlet-temperature is calculated by the TEMCO addition. In this manner appropriately-weighted temperature coefficients of reactivity can be obtained for the component feedback processes over subassemblies or regions of subassemblies desired for a kinetics-modeling of an EBR-II loading configuration. Also, in particular, the sum of the ratios of the positional reactivity for a given component to the corresponding positional temperature increment is an estimate of the contribution of that component to an overall isothermal temperature coefficient or inlet-coolant temperature coefficient. Temperature coefficients calculated by TEMCO correspond to the average temperature coefficients between the inlet-coolant temperature and 
the applicable positional temperature at the assumed reactor power and coolant flow rate.

The sums of the positional temperature coefficients for gross regions of EBR-II Run 93A are given in Table I. (The corresponding PRD components and power coefficients for this run are reported in Reference 3.) The listed components are due to: coolant densities relative to coolant temperatures, coolant displacements relative to structural temperatures, steel densities also relative to the structural temperatures, bond sodium relative to bond sodium temperatures if the gaps are open, fuel axial expansions relative to fuel temperatures, Doppler relative to fuel temperatures, and $\mathrm{B}_{4} \mathrm{C}$-fuel relative to the cooilant temperatures from fuel bottoms in control rods to the $\mathrm{B}_{4} \mathrm{C}$-follower bottoms in the control rods. The latter represents the reactivity effect caused by the separation of the $\mathrm{B}_{4} \mathrm{C}$-follower from the fuel rod due to axial expansion of the surrounding rod-can with temperature. The Doppler coefficients are here linearizations of the 60.0 MWt PRD Doppler components cver the fuel temperatures attained above inlet coolant temperature. The rod-bank suspension component is due to the cownward expansion of the control rods because of their overhead suspensions. Two temperature coefficients relative to inlet coolant temperature are also listed in Table I. These are the reactivity resulting from uniform radial expansion of the grid plate upon which the subassemblies are supported, and the reactivity resulting from the axially-upward movement of this grid together with it's lower support-structures which are also immersed in the primary sodium coolant. The latter causes the relative axial positionings of the overheadsuspended control rods and of the core to change. The resulting calculating inlet temperature coefficient or overall isothermal coefficient is $-25.1 \mathrm{x}$ $10^{-4} \% \Delta k / k$ per ${ }^{\circ} \mathrm{F}\left(-45.2 \times 10^{-4} \% \Delta k / k\right.$ per $\left.{ }^{\circ} \mathrm{C}\right)$. This corresponds to -1.11 Ih per ${ }^{\circ} \mathrm{F}\left(-2.00\right.$ Ih per $\left.{ }^{\circ} \mathrm{C}\right)$ or $-0.37 \phi$ per ${ }^{\circ} \mathrm{F}\left(-0.67 \phi\right.$ per $\left.{ }^{\circ} \mathrm{C}\right)$.

In Table II are listed the components of the temperature coefficients for the core-regions of the 72 metal-fueled sodium-bonded subassemblies, 16 oxidefueled he'ium-bonded subassemblies, 5 carbide-fueled helium-bonded subassemblies and 3 carbide-fueled sodium-bonded subassemblies, assuming the fuel-to- 
clad gaps to be either: all open, all closed with fuels free to move axially, or all closed with fuels axially restrained by the surrounding cladding. It is seen that the temperature coefficients of the fuel axial-expansion components are reduced by about $50 \%, 80 \%, 70 \%$, and $60 \%$, respectively, for these four fuel types if the fuels are assumed to be axially-restrained by the surrounding steel claddings instead of axially-expanding freely. The values corresponding to the distribution of gap conditions determined by the fuel burnup for this EBR-II loading are listed for comparisons. Included in the table are also the component coefficients for the sum of the 10 in-core nonfueled subassemblies.

References

1. E. M. Dean, H. A. Larson, "EROS: An Experimental Breeder Reactor II Operational Safety Code," Nucl. Technol., 57, 1, 7 (April 1982).

2. D. Meneghetti, D. A. Kucera, "EBRP0C0--A Program to Calculate Detailed Contributions of Power Reactivity Components of EBR-II," Proc. Int. Top?. Mtg. Advances in Mathematical Methods for the Solution of Nuclear Engineering Problems, Vol. 2, p. 225, Munich (1981).

3. David Meneghetti, Dwight A. Kucera, "Delineations of Power and Power-ioFlow Feedback Components of EBR-II," Trans. Am. Nucl. Soc., 53, 459 (1986). 


\section{TABLE 1. Temperature Coefficients of Reactivity $\left(10^{-4} \% \Delta k / k \text { per }{ }^{\circ} \mathrm{F}\right)^{a}$ for EBR-II Run 93A at 0-60.0 MW(th) Power Interval, \\ $\sim 8500 \mathrm{gpm}^{\mathrm{b}}$ at Pumps, and $11^{\mathrm{H} C}$ Rod Bank}

\begin{tabular}{|c|c|c|c|c|c|c|c|}
\hline & & & & & Fuel & & \\
\hline & Coolant & Coolant & Steel & Bond & Axial & & $\mathrm{B}_{4} \mathrm{C}$ \\
\hline & Density & Displ. & Density & Sodium & Exp. & Doppler & Fue? \\
\hline Core & -3.97 & -0.641 & -0.288 & -0.135 & -1.30 & -0.223 & +0.0644 \\
\hline Above Core & -2.06 & -0.338 & -0.294 & 0 & 0 & 0 & +0.00852 \\
\hline Below Core & -1.84 & -0.217 & -0.283 & -0.00908 & +0.0449 & +0.0445 & +0.0154 \\
\hline Rad Refl. & -1.46 & -0.703 & -1.04 & 0 & 0 & 0 & -- \\
\hline Rad Blkt. & -0.0933 & -0.0644 & -0.0333 & -0.0401 & -0.0836 & -0.302 & -- \\
\hline Rod-bank Su & pension & & -2.4 & & & & \\
\hline Grid-plate & adial-expa & ision & -5.6 & & & & \\
\hline $\begin{array}{c}\text { Lower Struc } \\
\text { Total }\end{array}$ & $\begin{array}{r}\text { ure Axial- } \\
-25.1 \\
\end{array}$ & Expansion & -1.9 & & & & \\
\hline
\end{tabular}

\footnotetext{
a. Multiply by 1.8 for $\% \Delta k / k$ per ${ }^{\circ} \mathrm{C}$.

b. $0.536 \mathrm{~m}^{3} / \mathrm{s}$.

c. $279 \mathrm{~mm}$.
} 
TABLE II. Comparisons of Core-region Temperature Coefficients of Reactivity $\left(10^{-4} \% \Delta k / k \text { per }{ }^{\circ} \mathrm{F}\right)^{\mathrm{a}}$ in EBR-II Run $93 \mathrm{~A}$ for

Subassembly Types and Various Gap Conditions

Fue?

\begin{tabular}{|c|c|c|c|c|c|c|c|}
\hline $\begin{array}{l}\text { No. of } \\
S / A^{\prime} S\end{array}$ & $\begin{array}{l}\text { S/A Type \& } \\
\text { Gap Condit. }\end{array}$ & $\begin{array}{l}\text { Coolant } \\
\text { Density }\end{array}$ & $\begin{array}{l}\text { Coolant } \\
\text { Displ. }\end{array}$ & $\begin{array}{c}\text { Steel } \\
\text { Density } \\
\end{array}$ & $\begin{array}{c}\text { Bond } \\
\text { Sodium } \\
\end{array}$ & $\begin{array}{l}\text { Axial } \\
\text { Exp. }\end{array}$ & Doppler \\
\hline $\begin{array}{l}72 \\
72 \\
72 \\
72\end{array}$ & $\begin{array}{l}M F(\mathrm{Na}) O G \\
M F(\mathrm{Na}) C G F F \\
M F(\mathrm{Na}) C G F R \\
M F(\mathrm{Na}) 93 \mathrm{~A}\end{array}$ & $\begin{array}{l}-2.50 \\
-2.50 \\
-2.50 \\
-2.50\end{array}$ & $\begin{array}{l}-0.42 \\
-0.42 \\
-0.42 \\
-0.42\end{array}$ & $\begin{array}{l}-0.17 \\
-0.17 \\
-0.17 \\
-0.17\end{array}$ & $\begin{array}{c}-0.59 \\
0 \\
0 \\
-0.091\end{array}$ & $\begin{array}{l}-1.54 \\
-1.58 \\
-0.75 \\
-1.17\end{array}$ & $\begin{array}{l}-0.17 \\
-0.17 \\
-0.17 \\
-0.17\end{array}$ \\
\hline $\begin{array}{l}16 \\
16 \\
16 \\
16\end{array}$ & $\begin{array}{l}\text { OF ( } \mathrm{He} \text { ) OG } \\
\text { OF ( He) CGFF } \\
\text { OF ( He) CGFR } \\
\text { OF ( He) } 93 \mathrm{~A}\end{array}$ & $\begin{array}{l}-0.56 \\
-0.56 \\
-0.56 \\
-0.56\end{array}$ & $\begin{array}{l}-0.073 \\
-0.073 \\
-0.073 \\
-0.073\end{array}$ & $\begin{array}{l}-0.031 \\
-0.031 \\
-0.031 \\
-0.031\end{array}$ & $\begin{array}{l}-- \\
-- \\
-- \\
--\end{array}$ & $\begin{array}{l}-0.15 \\
-0.14 \\
-0.031 \\
-0.058\end{array}$ & $\begin{array}{l}-0.028 \\
-0.030 \\
-0.030 \\
-0.030\end{array}$ \\
\hline $\begin{array}{l}5 \\
5 \\
5 \\
5\end{array}$ & $\begin{array}{l}\text { CF (He) } 0 \mathrm{G} \\
\text { CF (He)CGFF } \\
\text { CF (He)CGFR } \\
\text { CF (He) } 93 \mathrm{~A}\end{array}$ & $\begin{array}{l}-0.17 \\
-0.17 \\
-0.17 \\
-0.17\end{array}$ & $\begin{array}{l}-0.023 \\
-0.023 \\
-0.023 \\
-0.023\end{array}$ & $\begin{array}{l}-0.012 \\
-0.012 \\
-0.012 \\
-0.012\end{array}$ & $\begin{array}{l}-- \\
-- \\
--\end{array}$ & $\begin{array}{l}-0.061 \\
-0.058 \\
-0.018 \\
-0.042\end{array}$ & $\begin{array}{l}-0.0021 \\
-0.0024 \\
-0.0024 \\
-0.0022\end{array}$ \\
\hline $\begin{array}{l}3 \\
3 \\
3 \\
3\end{array}$ & $\begin{array}{l}\mathrm{CF}(\mathrm{Na}) O \mathrm{OG} \\
\mathrm{CF}(\mathrm{Na}) \mathrm{CGFF} \\
\mathrm{CF}(\mathrm{Na}) \mathrm{CGFR} \\
\mathrm{CF}(\mathrm{Na}) 93 A\end{array}$ & $\begin{array}{l}-0.089 \\
-0.089 \\
-0.089 \\
-0.089\end{array}$ & $\begin{array}{l}-0.014 \\
-0.014 \\
-0.014 \\
-0.014\end{array}$ & $\begin{array}{l}-0.0070 \\
-0.0070 \\
-0.0070 \\
-0.0070\end{array}$ & $\begin{array}{c}-0.019 \\
0 \\
0 \\
-0.019\end{array}$ & $\begin{array}{l}-0.037 \\
-0.037 \\
-0.014 \\
-0.037\end{array}$ & $\begin{array}{l}-0.0023 \\
-0.0022 \\
-0.0022 \\
-0.0023\end{array}$ \\
\hline 10 & $\begin{array}{l}\text { In-core non- } \\
\text { fueled }\end{array}$ & -0.22 & -0.068 & -0.055 & -- & -- & -- \\
\hline
\end{tabular}

a. Multiply by 1.8 for $\% \Delta k / k$ per ${ }^{\circ} \mathrm{C}$.

b. MF, OF, CF, (sodium or helium), OG, CGFF, and CGFR refer, respectively, to metal fuel, oxide fuel, carbide fuel, (bond), open gap, closed-gap fuelfree, and closed-gap fuel-restrained.

\section{DISCLAIMER}

This report was prepared as an account of work sponsored by an agency of the United States Government. Neither the United States Government nor any agency thereof, nor any of their employees, makes any warranty, express or implied, or assumes any legal liability or responsibility for the accuracy, completeness, or usefulness of any information, apparatus, product, or process disclosed, or represents that its use would not infringe privately owned rights. Reference herein to any specific cominercial product, process, or service by trade name, trademark, manufacturer, or otherwise does not necessarily constitute or imply its endorsement, recommendation, or favoring by the United States Government or any agency thereor. The views and opinions of authors expressed herein do not necessarily state or reflect those of the United States Government or any agency thereof. 